\title{
The removal of uranium from mining waste water using algal/microbial biomass
}

\author{
Margarete Kalin ${ }^{\mathrm{a}}$, W.N. Wheeler ${ }^{\mathrm{b}}$, G. Meinrath ${ }^{\mathrm{c}, *}$ \\ ${ }^{a}$ Boojum Research, 450 E. Queen St., Suite 101, Toronto, ON M5A 1T7, Canada \\ ${ }^{\mathrm{b}}$ W.N. Wheeler \& Associates, 23142 Arroyo Vista, Rancho Santa Margarita, CA 92680, USA \\ ${ }^{\mathrm{c}}$ RER Consultants, Schießstattweg 3a, D-94032 Passau, Germany
}

Received 1 September 2003; received in revised form 1 March 2004; accepted 4 May 2004

\begin{abstract}
We describe a three step process for the removal of uranium (U) from dilute waste waters. Step one involves the sequestration of $U$ on, in, and around aquatic plants such as algae. Cell wall ligands efficiently remove U(VI) from waste water. Growing algae continuously renew the cellular surface area. Step 2 is the removal of U-algal particulates from the water column to the sediments. Step 3 involves reducing U(VI) to U(IV) and transforming the ions into stable precipitates in the sediments. The algal cells provide organic carbon and other nutrients to heterotrophic microbial consortia to maintain the low $\mathrm{E}_{\mathrm{H}}$, within which the $\mathrm{U}$ is transformed.

Among the microorganisms, algae are of predominant interest for the ecological engineer because of their ability to sequester $U$ and because some algae can live under many extreme environments, often in abundance. Algae grow in a wide spectrum of water qualities, from alkaline environments (Chara, Nitella) to acidic mine drainage waste waters (Mougeotia, Ulothrix). If they could be induced to grow in waste waters, they would provide a simple, longterm means to remove $\mathrm{U}$ and other radionuclides from $\mathrm{U}$ mining effluents.

This paper reviews the literature on algal and microbial adsorption, reduction, and transformation of $U$ in waste streams, wetlands, lakes and oceans.

(c) 2004 Elsevier Ltd. All rights reserved.
\end{abstract}

Keywords: Uranium; Remediation; Bioremediation; Ecological engineering; Environmental chemistry

\footnotetext{
* Corresponding author. Tel./fax: +49-851-70-372.

E-mail address: meinrath@geo.tu-freiberg.de (G. Meinrath).
} 


\section{Introduction}

Uranium is a ubiquitous element. It is the heaviest element occurring in nature in weighable amounts. Despite its high atomic number, it is by no means a rare element. Its relative abundance in the earth crust compares to silver, gold and the light rare earth elements and it is more abundant than tin, mercury and lead. Its naturallyoccurring isotopes have masses of 238, 235 and 234. All isotopes are radioactive. The average U concentration in the earth's crust is about $3 \mathrm{mg} \mathrm{kg}^{-1}$. Concentrations of $\mathrm{U}$ in geological materials are highest in continental-type rocks. Uranium forms more than 160 mineral species and accounts for 5\% of all known minerals.

Dissolved $U$ is found in most natural waters at very low concentrations, but is of some concern in waters adjacent to $U$ mining operations when concentrations increase to levels above $1 \mu \mathrm{g} \mathrm{dm}^{-3} \cdot{ }^{238} \mathrm{U}$, the most common radionuclide, has a half-life of $4.5 \times 10^{9}$ years, which makes clean-up environmentally important (Meinrath et al., 1996). Currently, U removal from waste streams may be tackled in four ways: (i) direct chemical methods; (ii) electrochemical treatments; (iii) ion exchange and biosorption methods; or (iv) intracellular sequestration by growing plant, algal and microbial cells. Remediation by chemical and electrochemical treatment is expensive. For U leaching from tailings and underground workings, installations may have to be in place for thousands of years. Biosorption and sequestration by living plants provide an environmentally and economically favourable method for removing $U$ from natural waters. With proper engineering and development, an ecological self-regulating lowmaintenance solution can be implemented. To provide the scientific basis to the proposed bioremediation approach, this review concentrates on what is known about $\mathrm{U}$ and aquatic plants, especially the algae, which inhabit $\mathrm{U}$ waste waters.

A cost efficient means of $U$ removal is through the enhancement of a natural, ecological, three step process. The three steps are: (i) association of the U with organic particles (plants/algae/microbes) in the water column; (ii) provision of conditions whereby organic particles sink onto and into organic sediments; and (iii) provision of low $\mathrm{E}_{\mathrm{H}}$ (anaerobic) conditions in the sediments with metal-reducing microbial populations. The end result of this process is that oxidized $U$ associates with particulates, settles, becomes reduced and is bio-mineralized in the sediments effectively creating biogenic ores (Brierley and Brierley, 1981; Anderson et al., 1989a,b; Barton et al., 1996). The advantage of using living material in the initial step is that it continually grows, providing new organic material for sequestration. This is especially useful in flow-through systems, where the supply of $U$ to be removed is continuous. The ecological engineer must provide the proper conditions, nutrients, and organisms to optimize this three step process.

Examples from the lichens, algae, fungi, and bacteria are given, as these organisms contribute particulate and living matter to the aquatic habitat. The most common and diverse group in the aquatic environment are the algae. These organisms come in a variety of sizes and shapes, and occur in some of the most extreme environments on earth (Brock et al., 1984). Algae can be divided into a number of groups, functionally, taxonomically, and ecologically. For example, phytoplankton are algae that float in the water column; periphyton are mixed 
communities which are composed of algae with moss, fungi, and bacteria that grow on rocks, on macrophytic vascular plants and on sediment surfaces (Wetzel, 1983).

Some algae are more sensitive to pollutants than others. The most sensitive ones have been used in toxicity tests (Rojickova-Padrtova and Marsalek, 1999; Franklin et al., 2000). However, there are a number of algae that are widely tolerant to metals and $U$, and can sequester very high concentrations of metals. Some of the algaemicrobial systems can sequester metals and $U$ in concentrations far above the level in the surrounding water (e.g. Heide et al., 1973).

Several mechanisms have been described whereby U(VI) can be associated with algae: (i) adsorption to cell surfaces; (ii) adsorption to extracellular polysaccharides; (iii) uptake into cells and incorporation into vacuoles; (iv) incorporation into $\mathrm{CaCO}_{3}$ (aragonite) structures associated with some marine and freshwater algae; and (v) precipitation of $U$ on the cell surface or internally.

\section{Geochemistry}

$\mathrm{U}$ in nature does not occur in elemental form. In humid air, $\mathrm{U}$ corrodes rapidly forming yellow uranyl(VI) compounds, where the linear $[\mathrm{O}=\mathrm{U}=\mathrm{O}]^{2+}$ unit forms the characteristic structural unit. In the presence of phosphate(V), silicate, arsenate(V) and vanadate(V) highly insoluble orthophosphate, orthosilicate, orthoarsenate and orthovanadate compounds are formed, respectively. If these compounds are not present in significant quantities in water, the chemistry of hexavalent $\mathrm{U}$ is governed by its interactions with water and carbonate.

A larger group of uranyl hydroxides, oxyhydrates and uranates are known. The affinity of hexavalent $U$ to oxygen is extreme. There are very few oxygen-free U(VI) compounds. While $\mathrm{U}(\mathrm{V})$ has been reported from laboratory experiments, it is not stable enough to allow detailed investigation and, in any case, does not play an observable role in nature. U(IV) is hydrolyzed even at very low $\mathrm{pH}$. Freshly prepared U(VI) hydroxides show much higher solubility compared to uraninite minerals (Meinrath, 1998a and references given therein).

In Fig. 1, a speciation diagram of U(VI) in a dilute electrolyte solution is shown as a function of $\mathrm{pH}$ in equilibrium with solid phase schoepite (synthetic). Calculations are based on the IAEA (International Atomic Energy Agency) data base (IAEA, 1992). The $90 \%$ uncertainty limits (dashed lines) are calculated from the probabilistic speciation code Ljungskile (Ekberg et al., 2003; Ödegaard-Jensen et al., 2004). The calculations show the dominance of hydrolysis species in the acidic range while carbonato species prevail in the neutral to alkaline range. The $90 \%$ confidence ranges indicate the limited capability of such calculations to assess the likely species composition of a solution due to measurement uncertainties of thermodynamic data (Ödegaard-Jensen et al., 2004). A larger number of hydrolysis species, partly with an oligomeric nature, have been identified. The $90 \%$ confidence limits calculated in Fig. 1 show that a prediction of the dominating species is almost impossible.

Fig. 2 summarizes the redox behaviour of U(VI) (Meinrath et al., 2003). Carbonato species are likely to govern the redox stability of the U(IV) and U(VI) 


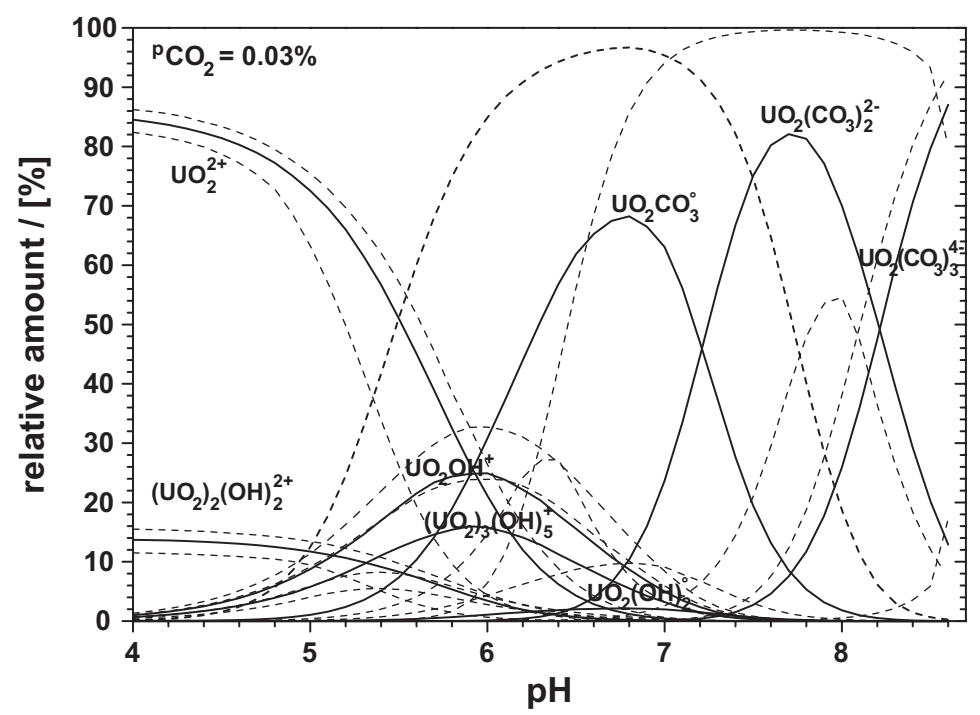

Fig. 1. Distribution of $\mathrm{U}(\mathrm{VI})$ aqueous complexes at $25{ }^{\circ} \mathrm{C}$ and ionic strength $\mu=0.01 \mathrm{M} \mathrm{NaCl}$ as a function of $\mathrm{pH}$ at atmospheric $\mathrm{CO}_{2}$ partial pressure. Dashed lines give $90 \%$ confidence limits. The uncertainty limits have been calculated on the basis of data from IAEA (1992).

redox state. However, large uncertainties exist with regard to the nature of U(IV) species and the stability of $\mathrm{U}(\mathrm{V})$. Assuming $\mathrm{U}(\mathrm{OH})_{4}{ }^{\circ}$ as the prevailing $\mathrm{U}(\mathrm{IV})$ solution species (smallest stabilization of U(V)), the stability field 'a)' (cf. Fig. 2) is obtained for $\mathrm{U}(\mathrm{V})$. For this situation, the species below the stability limit of $\mathrm{U}(\mathrm{V})$ is $\mathrm{U}(\mathrm{OH})_{4}{ }^{\circ}$ exclusively. The formation of U(IV) carbonato species results in a strong stabilization of $\mathrm{U}(\mathrm{V})$. On the basis of the highest formation constants reported for U(IV) carbonato species, the combined fields 'a)' and 'b)' account for the stability field of $U(V)$. Below the stability field of $U(V)$, the respective $U(I V)$ carbonato species are given in Fig. 2. Both situations, however, are in disagreement with experimental observations. Figs. 1 and 2 illustrate the large uncertainties that hamper the predictive power of thermodynamic simulations in $U$ environmental chemistry. In assessing Fig. 2 it should be noted that the formation of U(IV) from U(VI) involves breaking two extremely stable U-O bonds. Hence, high overpotentials must apply, thus rendering redox state predictions on the basis of mere thermodynamic equilibrium calculations doubtful.

\section{Stage 1: uranium sequestration}

\subsection{Adsorption}

The observation that algae and aquatic macrophytes have a strong affinity for $\mathrm{U}$ (Scheminzky, 1959; Justyn and Stanek, 1974) led to the recognition that they could 


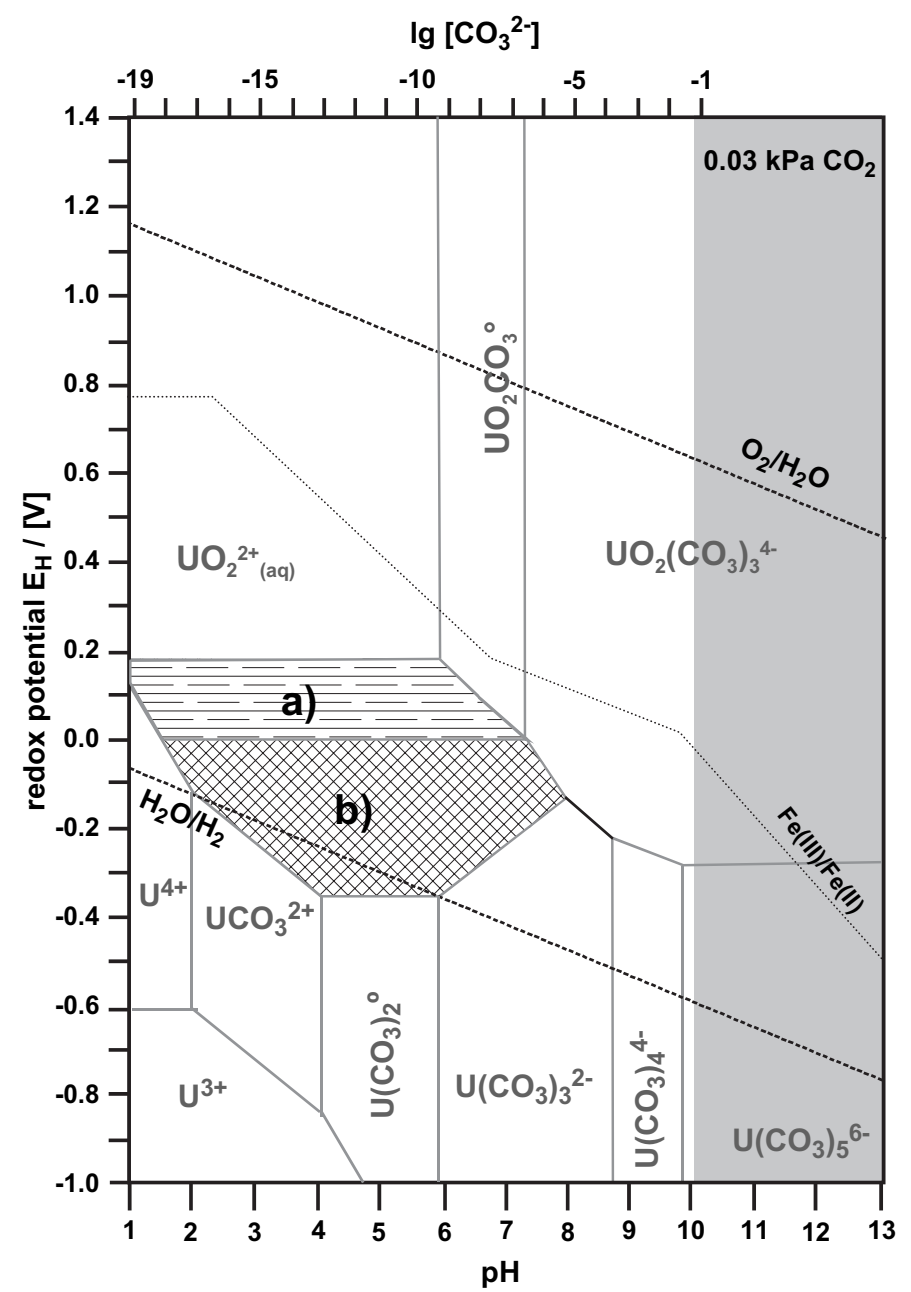

Fig. 2. $\mathrm{E}_{\mathrm{H}} / \mathrm{pH}$ diagram for uranium species at $25^{\circ} \mathrm{C}$ and $1013 \mathrm{hPa}$ in the $\mathrm{U} / \mathrm{H}_{2} \mathrm{O} / \mathrm{CO}_{2}$ system; ${ }^{\mathrm{p}} \mathrm{CO}_{2}=30$ $\mathrm{Pa}$. The field a) gives the calculated stability field of $\mathrm{U}(\mathrm{V})$ if the stable $\mathrm{U}(\mathrm{IV})$ species is $\mathrm{U}(\mathrm{OH})_{4}{ }^{\circ}$, while both fields 'a)' and 'b)' give the calculated stability field of U(V) if the U(IV) carbonate species are prevailing solution species. In both cases, calculations are in disagreement with experimental observations. The stability range of water is limited by the oxidation and reduction boundaries, respectively. These limits are given as dashed lines denoted ' $\mathrm{O}_{2} / \mathrm{H}_{2} \mathrm{O}$ ' and ${ }^{\prime} \mathrm{H}_{2} \mathrm{O} / \mathrm{H}_{2}$ ', respectively. These boundaries are $\mathrm{pH}$ dependent. The line denoted ' $\mathrm{Fe}$ (III)/ $\mathrm{Fe}$ (II)' gives the redox boundary between trivalent and divalent iron hydroxide species. It indicates that $\mathrm{Fe}(\mathrm{III})$ is capable of reoxidizing $\mathrm{U}(\mathrm{IV})$. The shaded area is physically not accessible because the carbonate content would exceed the limit of ionic strength.

provide a means of removing $U$ from waste water. Heide et al. (1973) suggested that unicellular green algae in continuous culture could remove $95 \%$ of the dissolved $U$ from seawater, with accumulation factors greater than 4000. Pribil and Marvan (1976) studied the U adsorption characteristics of another unicellular green alga with 
similar results. Horikoshi et al. (1979, 1981) and Nakajima et al. (1979) confirmed the usefulness of algae as $U$ adsorbents. Both cell wall structure and the U(VI) ion contribute to $\mathrm{U}$ adsorption by algae both in seawater and freshwater.

Biologically, metal ions are classified by their binding preferences, specifically whether they seek out O-, N-, or S-containing ligands. Pearson (1963) separated metal ions into hard acids (O-seeking) and soft acids ( $\mathrm{N}$ - or S-seeking). Binding sites sought by hard acids on biological surfaces include carboxylate, carbonyl, alcohol, phosphate, and phosphodiester groups (ligands). Groups sought by soft acids include sulphide, disulphide, thioether, and amino groups (see Table 1).

Most plant, algal, or microbial materials found in natural waters have cell walls composed mainly of polysaccharides and carbohydrates, e.g. cellulose, xylan, and mannans (Lobban and Wynne, 1981; Myers et al., 1975; Neihof and Loeb, 1972), with a negative charge on their surfaces. The negatively charged groups attract cations such as $\mathrm{Zn}, \mathrm{Cu}, \mathrm{Al}$ and $\mathrm{U}$ (Barker et al., 1998; Marques et al., 1990). The polysaccharide backbone contains many other side groups, ligands such as amino, carboxyl or hydroxy, sulphide groups. These groups provide the cell wall with an overall negative charge. See Tables 1 and 2 for a list of ligands and their composition. Uranium can also be adsorbed to inorganic ligands. Zero valent iron immobilizes U(VI) (Farrell et al., 1999; Gu et al., 1998) by the formation of iron hydroxides (ferrihydrite, goethite) (Duff and Amrhein, 1996; Morrison et al., 1995; Wielinga et al., 1999, 2000; Noubactep et al., 2003).

Most metals that are adsorbed or complexed to negatively charged cell walls are bound to the negatively charged ligand groups on the surface. However, some groups carry a positive charge and are thus able to adsorb and complex anionic

Table 1

List of ligand groups and their $\mathrm{p} K_{\mathrm{s}}$ (Hunt, 1986; Segel, 1976)

\begin{tabular}{lll}
\hline Ligand group & Location & $\mathrm{p} K_{\mathrm{s}}$ \\
\hline Carboxyl & Protein c-terminal & $3.5-4$ \\
Carboxyl & Beta aspartic & $4-5$ \\
Carboxyl & Gamma glutamic & $4-5$ \\
Carboxyl & Uronic acid & $3-4.4$ \\
Carboxyl & $N$-Acetylneuraminic & 2.6 \\
Carboxyl & Lactate & 3.8 \\
Sulphonic acid & Cysteic acid & 1.3 \\
Phosphate & Serine as ester & $6.8,2.0$ \\
Phosphate & Polyol mono ester & $0.9-2.1$ \\
Phosphate & Polysaccharide diester & $1.5,6.0$ \\
Amino & Cytidine (pyrimidine) & 4.11 \\
Amino & Adenosine (purine) & 3.45 \\
Imidazole & Histidine & $6-7$ \\
Hydroxyl & Tyrosine-phenolic & $9.5-10.5$ \\
Hydroxyl & Saccharide-alcoholic & $12.0-13.0$ \\
Sulphide & Cysteine & 8.3 \\
Amino & Protein N-terminal & $7.5-8.0$ \\
Amino & Lysine & $8.9,10.5$ \\
Imino & Peptide & 13 \\
\hline
\end{tabular}


Table 2

Sorption capacities of uranium(VI) for different taxa ( $\mathrm{pH}$ is $\mathrm{pH}$ at which measurements were taken)

\begin{tabular}{|c|c|c|c|c|}
\hline Taxon & Model & $\begin{array}{l}\text { Sorption } \\
\text { capacity } \\
\left(\mathrm{mg} U \mathrm{gdm}^{-1}\right)\end{array}$ & Measured $\mathrm{pH}$ & Reference \\
\hline Scenedesmus & Measured & 75 & & Zhang et al. (1997) \\
\hline Chlorella & Measured & 15.6 & & Horikoshi et al. (1979) \\
\hline Chlorella & Measured & 28.5 & $(\mathrm{pH} 3.5)$ & McCready and Lakshmanan (1986) \\
\hline Sargassum & Langmuir & 560 & $(\mathrm{pH} 4.0)$ & Yang and Volesky (1999b) \\
\hline Sargassum & Langmuir & 330 & $(\mathrm{pH} 3.2)$ & Yang and Volesky (1999b) \\
\hline Sargassum & Langmuir & 150 & $(\mathrm{pH} 2.6)$ & Yang and Volesky (1999b) \\
\hline Sargassum & Measured & 524 & & Fourest and Volesky (1997) \\
\hline Pseudomonas & Measured & 96,000 & & Marques et al. (1990) \\
\hline Pseudomonas & Measured & 541 & Lyophilized & Sar and D'Souza (2001) \\
\hline Pseudomonas & Measured & 410 & Live at pH 5 & Sar and D'Souza (2001) \\
\hline Saccharomyces & Measured & 571 & & Omar et al. (1996) \\
\hline Saccharomyces & Measured & 360 & & Riordan et al. (1997) \\
\hline Saccharomyces & Measured & 138 & & Volesky and May-Phillips (1995) \\
\hline Kluyveromyces & Measured & 180 & & Bustard et al. (1996) \\
\hline Talaromyces & Langmuir & 323 & (pH 5) & Bengtsson et al. (1995) \\
\hline Aspergillus & Langmuir & 423 & & Bhainsa and D'Souza (1999) \\
\hline Aspergillus & Measured & 40 & $(\mathrm{pH} 4-5)$ & Hafez et al. (1997) \\
\hline Rhizopus & Measured & $>180$ & $(\mathrm{pH} 4)$ & Bhainsa and D'Souza (1999) \\
\hline Rhizopus arrhizus & Measured & 42.3 & $(\mathrm{pH} 3.5)$ & McCready and Lakshmanan (1986) \\
\hline Penicillium spp. & Measured & 20.3 & $(\mathrm{pH} 3.5)$ & McCready and Lakshmanan (1986) \\
\hline Peltigera & Measured & 42 & $(\mathrm{pH} 4-5)$ & Haas et al. (1998) \\
\hline Cladonia & Measured & 29 & & Haas (1998) \\
\hline Umbilicaria & Measured & 10 & & Haas (1998) \\
\hline
\end{tabular}

metal species. The mixture of these groups on a given cell surface will determine the number of cations and anions that are complexed. Since the chemical composition and cell size are reasonably constant for a given algal species, the number of ligand groups on an alga's surface should also be fixed. More than one ligand type can be found on a given cell surface, which results in the selectivity of each cation/ligand. Various functional groups have different affinities for binding of cations and anions and thus different stability constants. Thus, a spectrum of stability constants with changing cation/surface ligand ratios can be found in natural assemblages. For example, copper $\left(\mathrm{Cu}^{2+}\right)$ will tend to bind first to amino acid surface groups, then to carboxylic or hydroxy-carboxylic groups (Williams, 1981).

A plausible number of high affinity surface binding sites is about $10^{7}-10^{8}$ per cell for a representative phytoplankter (Morel and Hudson, 1985). Thus, some algae can have a higher affinity for some cations than others. In its cation form, $U$ can be 'adsorbed' onto most cell surfaces. Binding anionic, complexed species of $U$ is more difficult, as there are fewer positively charged ligands. The number of ligand sites for $\mathrm{U}(\mathrm{VI})$ on the bacterium Shewanella putrefaciens (Gamma Proteobacteria) was calculated to be approximately $32 \mu \mathrm{mol}$ carboxyl sites, $9 \mu \mathrm{mol}$ phosphoryl sites and $38 \mu \mathrm{mol}$ amine ligand sites per gram wet weight of bacteria. These values correspond 
to $2.0 \times 10^{19}$ carboxyl sites, $5.5 \times 10^{18}$ phosphoryl sites, and $2.3 \times 10^{19}$ amine sites per gram of bacteria (Haas et al., 2001).

The cell wall structure of a bacterium, Mycobacterium smegmatis (Actinobacteria), has been analyzed for its carboxyl group content by Andres et al. (1994). Electron microscopic analysis of the cell surfaces and separation of the arabinogalactan-peptidoglycans (AGP) from the cell matrix indicate that about $100 \mathrm{mg} \mathrm{U}$ could potentially be adsorbed per gram cell dry weight. AGP is composed primarily of polypeptides with carboxyl groups. Approximately $200 \mathrm{nmol}$ of AGP per gram dry weight of bacterium was found to be present.

At given $\mathrm{E}_{\mathrm{H}}, \mathrm{pH}$ and chemical conditions, several $\mathrm{U}$ species may prevail (Fig. 1). The speciation of $U$ in solution regulates the $U$ ion concentration and influences the resulting complexation reaction. The concentration of ligand sites is then proportional to the organic carbon, phosphorus, and nitrogen content of a cell suspension. If surface sites with very high affinity for certain cations exist, cell surface sites may become saturated with those cations. If the $\mathrm{U}$ ions were in excess of the concentration of high affinity sites, the surface of the cells could carry a constant concentration of $U$ with respect to the cell composition. If the cells are growing, the number of available surface sites increases; in other words, the rate at which $U$ ions are removed from solution is a function of growth rate.

Dienemann et al. (2002) characterized the U content of algae growing in wetlands in $U$ mine effluents. They describe the algae as efficient, temporary sinks for $U$. Bioadsorption of up to $300 \mathrm{mg}$ of $\mathrm{U}$ per $\mathrm{kg}$ dry matter (mass) led the authors to believe that algae might be useful in the removal of $U$ from the waste stream. However, they caution that changes in $\mathrm{E}_{\mathrm{H}} / \mathrm{pH}$ conditions can remove the $\mathrm{U}$. If the chemical conditions change, i.e. by addition of dissolved ligands (e.g. EDTA) or pH change, bound $\mathrm{U}$ can be released. For example, if $\mathrm{pH}$ drops significantly, then $\mathrm{H}^{+}$ concentrations, by definition, increase. Dropping $\mathrm{pH}$ implies release of U.

Some plant/microbe populations release extracellular polysaccharides as a byproduct of metabolism. These extracellular polysaccharides also contain ligands which can bind metal ions (Rai et al., 1981). Microbes such as Pseudomonas (Gamma Proteobacteria), and Citrobacter (Omnibacteria) also produce large quantities of extracellular polysaccharides (Liu and $\mathrm{Wu}, 1993$; Marques et al., 1990), which can complex U. Marques et al. (1990) studied the removal of U by Pseudomonas exopolysaccharides. They found the complexation to be affected by $\mathrm{pH}$, but not temperature. Complexation was best approximated by Freundlich isotherms, suggesting sequestration being limited to a single layer.

Other dissolved ligands that bind $U$ include the humic and fulvic substances found in peat bogs and acidic lakes (Titayeva, 1967; Halbach et al., 1980). Titayeva (1967) conducted both dynamic and static sorption tests on Ra and U on peat. U was sorbed better than Ra from weakly weak acid solutions (peat and water) under static conditions. Increasing the $\mathrm{pH}$ from 5 to 8 increased the adsorption of Ra, while the optimum $\mathrm{pH}$ for $\mathrm{U}$ was $\mathrm{pH}$ 6. Desorption tests using alkali extraction showed that $\mathrm{Ra}$ was mainly sorbed to the insoluble matrix, while most of the $\mathrm{U}$ desorbed with increasing alkali treatment, suggesting that it was associated with the humic substances. 
The interaction of humic substances with $U$ binding to algal cells was also studied by Szalay (1964). The adsorptive properties of humic acids probably relate to the carboxyl and hydroxyl groups associated with the breakdown of lignin. The carboxyl group, he notes, has a dissociation constant $\mathrm{p} K_{\mathrm{s}} \sim 5$. Hence the carboxyl group accepts $U$ at about the optimum $\mathrm{pH}$ for $\mathrm{U}$ removal. Uranium is not reduced by interaction with humic acids, but rather is strongly adsorbed (Nash et al., 1981). Szalay (1964) likened humic acids to cation exchange columns, and found that Langmuir iso-pH curves described well the adsorption equilibrium of humic acids (see section on Modelling). The Langmuir equation is characterized by two constants representing a geochemical enrichment factor (GEF) and the adsorption capacity. The GEF is defined as:

$$
\mathrm{GEF}=\frac{\text { conc. of } \mathrm{U}(\mathrm{VI}) \text { in peat }}{\text { conc. of } \mathrm{U}(\mathrm{VI}) \text { in water }}
$$

GEF was measured at approximately 10,000.

Degens et al. (1979) describe the transformation of $U$ emanating from an old underground mine into a shield lake. The $U$ found in the sediments was associated almost completely with both phytoplankton debris and humic acids.

Living and dead cells behave in a similar fashion with respect to adsorption of $U$, provided the cell wall structure remains intact. Since the cell walls of dead algae/ microbes and plants still contain negatively charged ligands and the overall charge of the cell wall is still negative, the dead plant material will, to some degree, adsorb positively charged $\mathrm{U}$. This method has been the choice of those who would try to put adsorption into a more industrial process. Thus, several authors have reported on the use of dead biomass to adsorb cations from solution (Tsezos and Volesky, 1982; Volesky and May-Phillips, 1995; Greene et al., 1986).

The Langmuir isotherm (Langmuir, 1918) is a means to interpret hyperbolic adsorption data. It is basically the same equation used to describe Michaelis-Menten enzyme kinetics, and describes the adsorption of ions to a finite number of ligand sites in a single layer on the cell surface. Thus,

$$
C_{\mathrm{s}}=C_{\mathrm{s}(\mathrm{sat})} K_{\mathrm{L}} C_{\mathrm{w}} /\left(1+K_{\mathrm{L}} C_{\mathrm{w}}\right)
$$

or in a linear form:

$$
1 / C_{\mathrm{s}}=\left(1 / C_{\mathrm{w}}^{*}\right)\left(1 / K_{\mathrm{L}}\right)+\left(1 / C_{\mathrm{s}(\mathrm{sat})}\right)
$$

where $C_{\mathrm{s}}$ is the concentration of uranyl on the algal surface $\left(\mathrm{mg} \mathrm{kg}^{-1}\right), C_{\mathrm{s}(\mathrm{sat})}$ is the monolayer saturation concentration of uranyl on the algal surface (adsorption capacity: $\mathrm{mg} \mathrm{kg}^{-1}$ ), $K_{\mathrm{L}}$ is a constant related to the binding energy of uranyl to the algal surface $\left(\mathrm{L} \mathrm{mg}^{-1}\right)$, and $C_{\mathrm{w}}$ is the concentration of uranyl in water $\left(\mathrm{mg} \mathrm{dm}^{-3}\right)$.

There are certain assumptions inherent in using the Langmuir isotherm. First, the sorbent has a fixed number of sites. Second, all of the sites have equal binding enthalpies, independent of the extent of coverage. Third, maximum sorption is a monolayer on the substrate surface. 
The Freundlich isotherm (Freundlich, 1926) is another common model that has no theoretical basis. The shape of the adsorption curve, however, depends on the constants $K_{\mathrm{d}}$ and $N$. The Freundlich equation can be linearized by plotting the $\ln$ of $C_{\mathrm{s}}$ against the $\ln$ of $C_{\mathrm{w}}$. The slope of the $\ln / \ln$ plot is $1 / N$ and the $\ln K_{\mathrm{d}}$ is the $y$ intercept at $\ln C_{\mathrm{w}}=1$.

In this case, $K_{\mathrm{d}}$ is proportional to the maximum adsorption constant of the Langmuir isotherm. Specifically, the Freundlich $K_{\mathrm{d}}$ represents the predicted amount of metal/actinide sorbed in milligrams per gram of sorbent at an equilibrium concentration of $1 \mathrm{mg} \mathrm{dm}^{-3}$ (Tien, 2002). It is an empirical parameter that is composed of three components, a binding constant, a term related to the number of adsorption sites, and solution composition. Solution composition is constant for any given water sample, so only the binding constant and the number of surface sites contribute to variation among $K_{\mathrm{d}}$ s. Binding energy decreases as the number of sites are filled, and so is a constant only at low sorbent concentrations. The number of surface sites will depend on the cell surface composition. The parameter $N$ is a measure of the affinity between the sorbent and the surface. The forces between the surface layer and the sorbent are attractive if $N$ is less than unity and repulsive if $N$ is greater than unity (Ozer et al., 1999). Freundlich $1 / N$ could be estimated based on the structure of the adsorbent cell surface and the density of carboxyl groups on that surface (Chang et al., 2000).

$$
\begin{aligned}
& C_{\mathrm{s}}=K_{\mathrm{d}} C_{\mathrm{w}}^{1 / N} \\
& \log \left(C_{\mathrm{s}}\right)=(1 / N) \log \left(C_{\mathrm{w}}\right)+\log \left(K_{\mathrm{d}}\right)
\end{aligned}
$$

where $C_{\mathrm{s}}$ is the concentration of uranyl on the algal surface $\left(\mathrm{mg} \mathrm{kg}^{-1}\right), K_{\mathrm{d}}$ is the constant related to the specific capacity of uranyl to algae surface, $C_{\mathrm{w}}$ is the concentration of uranyl in water $\left(\mathrm{mg} \mathrm{dm}^{-3}\right)$ and $N$ is a function of the intensity of adsorption.

However, speciation of hydroxo- and carboxylato species of $\mathrm{U}$ is highly $\mathrm{pH}$ dependent. Small changes in $\mathrm{pH}$ may strongly affect the equilibrium (Meinrath, 1997, 1998b). Note here that competition with other cations can modify the binding of $U$ to cell surfaces. If the chemical conditions change, such as an addition of other ligands to the water (e.g. EDTA) or a change in $\mathrm{pH}$, bound $\mathrm{U}$ can be released.

\subsection{Active intracellular uptake}

Algae and other aquatic plants are known to actively pump metals across their cell membranes. This requires an energy source, and is therefore usually coupled to photosynthesis and temperature. Since large numbers of metals in the environment are essential nutrients, it is not surprising that many metals are actively pumped into algal cells. The problem arises when the external metal concentrations far exceed cell requirements. While $U$ is not a required nutrient, it may mimic a metal that is required. Whatever the reason, $\mathrm{U}(\mathrm{VI})$ is taken up by some algal cells. Once inside the cell, $\mathrm{U}$ is concentrated into vacuoles and sometimes precipitated. For example, Pribil 
and Marvan (1976) working with Scenedesmus (Chlorophyta) found that U accumulation occurred in two steps, a fast and a slow step. The second, slower step appeared to be temperature-dependent, and thus may have indicated some active uptake of U(VI). Mann and Fyfe $(1984,1985)$ found U(VI) crystals inside the algal cells of Spirogyra (Chlorophyta). Some authors looked for but could find no evidence of an active uptake in diatoms (Bacillariophyta; Goldberg et al., 1998) or Chlorella (Chlorophyta; Horikoshi et al., 1981).

Other organisms have also been shown to actively take up uranyl ions. For example, Golab et al. (1991) studied the biosorption of uranyl ions in Streptomyces (Actinobacteria) in competition with lead ions. Uranyl was found to be extracellular and intracellular, while the lead was found only extracellularly. Peltigera (Lichen) has been shown to take up $U$ and, together with internal inorganic phosphate, to create uranium-phosphate crystals which are stored in the cellular mycobiont (not the alga) (Barker et al., 1998). Krueger et al. (1993) estimated that about $10 \%$ of the Pseudomonas fluorescens cells studied contained internal U above trace levels. They also noted that internally located U ultimately killed the cells.

\subsection{Bio-precipitation}

Another means of complexing metals and $U$ with algae is through the process of bioprecipitation. This process usually occurs outside the cell, but it can occur inside as well. By setting up surface currents and changing $\mathrm{E}_{\mathrm{H}} / \mathrm{pH}$ conditions on the cell surface, algae can affect the geochemical conditions of the water around them, facilitating the precipitation of metals. For example, Kalin and Wheeler (1992) described a situation where algal mats altered the geochemical environment by fostering $\mathrm{Zn}$ carbonate precipitation in and around the algal mats.

Mann and Fyfe (1984) found a species of Ankistrodesmus (Chlorophyta) growing in effluent from a U mine in Elliot Lake, Canada. When electron microscope pictures of the alga were taken, cubic crystals of a $U$ oxide were found decorating the surface of the cells. This alga, like others, probably behaves in a similar fashion to certain bacteria which are known to precipitate metals on their cell surfaces. The interaction of metal ions with bacterial surfaces is at least a two step phenomenon (Beveridge and Murray, 1980). The first event is a stoichiometric interaction between metal ion and reactive surface ligands on the cell walls. This event lowers the energy barrier for additional metal complexation and nucleates the precipitation of additional metal. As metal ions are added to the nucleation site, counter ions in solution dictate the chemical composition of the precipitate so that metal hydroxides, carbonates, sulphates, sulphides, phosphates, etc. can be formed. The eventual mineral phase is determined by the availability of metal, counter ion, and the chemical solution $(\mathrm{pH}$, $\mathrm{E}_{\mathrm{H}}$, etc.). Over time, these hydrous precipitates dehydrate and bona fide crystalline mineral phases are developed (McLean and Beveridge, 1990). Basnakova et al. (1998) described similar uranyl phosphate crystals in Citrobacter (Omnibacteria).

In analyzing several species of tropical seaweeds (Chlorophyta, Phaeophyta, Rhodophyta) that incorporate calcium carbonate in their cell walls, Edington et al. (1970) noted that there was a very high correlation between the concentration of Ca 
and $U$ in red algae (Rhodophyta). The authors suggest that there are two mechanisms involved in the concentration of $U$. The first and primary mechanism is ion exchange or co-precipitation of the ion with the calcium carbonate matrix, and the second is a secondary mechanism that involves some form of complex formation with either the protein nitrogen or other component of the organic fraction. At given $\mathrm{pH}, \mathrm{pCO}_{2}$, and $\mathrm{E}_{\mathrm{H}}$ of seawater, $\mathrm{U}$ is most likely to occur as the anionic species $\mathrm{UO}_{2}\left(\mathrm{CO}_{3}\right)_{3}^{4-}$ (Noubactep et al., 2003) (Fig. 2). Therefore, the U(VI) ion may not be readily available for the formation of organic complexes unless these are more stable than the $\mathrm{UO}_{2}\left(\mathrm{CO}_{3}\right)_{3}^{4-}$ complex. The structure of the $\mathrm{U}(\mathrm{VI})$ carbonato species is similar to those of analogous actinyl carbonate compounds (Meinrath, 1996). The $\mathrm{U}(\mathrm{VI})$ tricarbonato species is one of the most stable metal complexes in aqueous solution. It would readily be incorporated with calcium carbonate (or undergo anion exchange reaction) in those species of algae in which calcification occurs. In the human body, $U$ is incorporated mainly in bone materials (Meinrath et al., 2003 and references given therein).

Phosphate can also form crystalline structures with $U$ (Bloch, 1980). The U(VI) phosphates are very stable and have been used as a possible means to remove $U$ from waste waters (Wright and Conca, 2002). Indirect evidence for such a relationship between $U$ and phosphate is detailed by Abu-Hilal (1994), who noted that Red Sea corals, algae, and seagrasses collected from a phosphatepolluted site all had elevated $U$ as compared with organisms from nearby sites with $\mathrm{U}$ at geogenic levels. A lichen, Peltigera, has been shown to take up $\mathrm{U}$ and together with internal inorganic phosphate to create U(VI) phosphate crystals which are stored in the cellular mycobiont (Barker et al., 1998). This formation of $\mathrm{U}(\mathrm{VI})$ phosphate crystals is widespread, although it is more likely to be found on the surface of cells (Thomas and Macaskie, 1998). Citrobacter (bacteria) precipitates U(VI) and other heavy metals on its cell surfaces as metal phosphates (Roig et al., 1997). Macaskie et al. (2000) describe the process whereby Citrobacter produces an overabundance of alkaline phosphatase, which in turn causes the cells to excrete phosphate, which provides the nucleus for the precipitation of $\mathrm{U}(\mathrm{VI})$ phosphate on cell surfaces.

\subsection{Competition}

In fresh water, algae and microbes live under conditions which can extend from pH 12 down to $\mathrm{pH} 1$ (Brock et al., 1984). Most natural waters, however, show pH values between 6 and 8. Many studies with algae reported an optimum pH for U removal. Invariably, the $\mathrm{pH}$ was acidic to neutral. As $\mathrm{pH}$ climbed above neutral, the removal rate and absolute amounts removed dropped considerably. For example, for Anacystis (Cyanobacterium), the optimum pH range was between 3.0 and 5.0 for U removal (Liu and Wu, 1993). Yang and Volesky (1999b) used protonated Sargassum (Phaeophyta) to remove U. The optimum $\mathrm{pH}$ ranged between 2.5 and 4.0. In another example, the bioaccumulation of $U$ by green algae was favoured in waters with higher calcium carbonate ratios, which had lower $\mathrm{pH}$ values than waters with higher calcium carbonate ratios (Duff et al., 1997a). Scenedesmus (Chlorophyta) 
showed an accumulation optimum plateau between pH 5 and 8.5 (Zhang et al., 1997), or between 5.9 and 6.8 (Pribil and Marvan, 1976). Horikoshi et al. (1979) found a $\mathrm{pH}$ optimum for $\mathrm{U}$ uptake in Chlorella regularis between $\mathrm{pH} 6$ and 7.

Not only are algae more likely to remove $U$ under acidic conditions, but so also are lichens. Boileau et al. (1985) exposed $U$ in the form of uranyl ions which had been pretreated to make them a cation, anion, or neutral to Cladonia (lichen). The maximum observable removal capacities were $49 \mu \mathrm{mol} \mathrm{gdm}^{-1}$ for positively charged uranyl species, $17 \mu \mathrm{mol} \mathrm{gdm}^{-1}$ for neutral uranyl species, and $1.6 \mu \mathrm{mol} \mathrm{gdm}^{-1}$ for negatively charged uranyl species. Haas et al. (1997) produced the same trends for Peltigera (lichen). The best $\mathrm{pH}$ for $\mathrm{U}$ accumulation is reported to be between 4 and 5 . Since most plant cell walls are similar to algae and fungi, we can expect that under most conditions, $\mathrm{U}$ uptake/adsorption will be higher under acidic conditions. All of these acidic optima correspond to the fact that carboxyl, amino and phosphate ligands are probably the major complexing agent on/in the cell walls. These ligands have $\mathrm{p} K_{\mathrm{s}}$ values in the $\mathrm{pH}$ range from 3 to 5 .

Competition for sites on cell walls is strongly $\mathrm{pH}$-dependent. $\mathrm{H}^{+}$ions behave just like any other cation. At $\mathrm{pH}$ values below $5, \mathrm{H}^{+}$concentrations are high enough to compete with other metals in solution. At $\mathrm{pH}$ values below $2, \mathrm{H}^{+}$outcompetes other metals and strips them from the ligands. Disregarding $\mathrm{H}^{+}$ions as competitors, researchers have looked at the competition of $\mathrm{U}(\mathrm{VI})$ with other metals. When in mixtures, U(VI) and other metals will compete based on molecular size and shape and the configuration of the ligand. For example, Zhang et al. (1997) grew Scenedesmus (Chlorophyta) in laboratory culture and then submitted it to a variety of $\mathrm{U}$ uptake experiments. Lithium, $\mathrm{Na}, \mathrm{K}$, and $\mathrm{NH}_{4}$ did not affect $\mathrm{U}$ accumulation. However, the transition group of metals did compete with U(VI). Bhainsa and D'Souza (1999) ran a similar set of experiments with Aspergillus (ascomycota). Again, the optimum $\mathrm{pH}$ was 5, but no inhibitory effect from the addition of such ions as $\mathrm{Fe}, \mathrm{Ca}$, or $\mathrm{Zn}$ was observed. However, $\mathrm{Al}$ did interfere with $\mathrm{U}$ removal. Tsezos et al. (1997) also found that Al interfered with $\mathrm{U}$ biosorption in Rhizopus (Zytomycota). Liu and Wu (1993), working with Anacystis nidulans (Cyanobacteria), noted that of those metal ions tested, only $\mathrm{Ca}, \mathrm{Fe}$, and $\mathrm{Zn}$ had any appreciable effect on $\mathrm{U}$ accumulation. Iron was, by far, the most competitive ion, reducing $U$ accumulation by $80 \%$. The effect of various cations and anions on the uptake of $U$ by Chlorella regularis (Chlorophyta) was examined by Nakajima et al. (1979). Uranium uptake was hindered by phosphate and carbonate ions and was not affected by cations ( $\mathrm{Na}, \mathrm{K}, \mathrm{Mg}, \mathrm{Ca}, \mathrm{Mn}, \mathrm{Co}, \mathrm{Ni}$, and $\mathrm{Zn}$ ), nitrates, sulphates, and thiosulphates. Since the amount of $U$ taken up decreased linearly with the amounts of carbonate added, the authors suggested that only the cation form of U(VI) was being complexed, in a manner similar to other metallic cations.

Information on experimental conditions of U 'uptake' studies, e.g. starting $\mathrm{pH}$ and total initial $U$ concentration, is partly difficult to interpret. In some cases, starting conditions instead of steady-state conditions are specified in the text. In other cases, conditions must be read from figures. In Fig. 3, selected data from the references are summarized and compared to the experimental solubility curve of synthetic schoepite $\left(\mathrm{UO}_{3} \cdot 2 \mathrm{H}_{2} \mathrm{O}\right)$ in $0.1 \mathrm{M}$ perchlorate medium (Meinrath et al., 1996; 


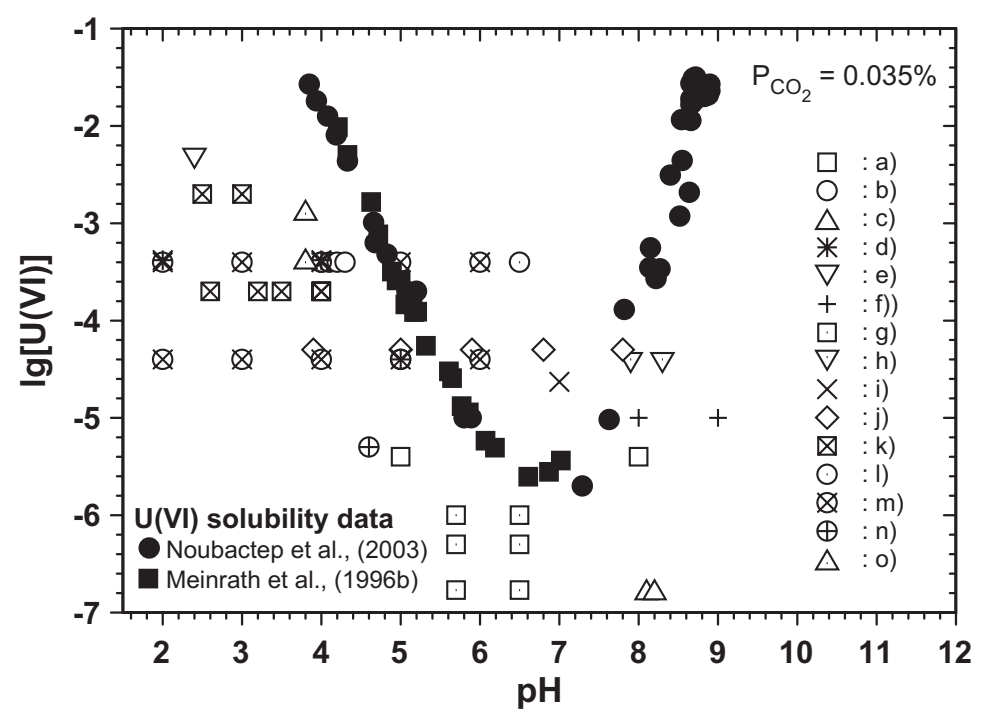

Fig. 3. Comparison literature data on experimental conditions for U uptake studies into cells with U(VI) solubilities at $I=0.1 \mathrm{M}$. Studies were mainly performed in low $\mathrm{pH}$ media with total $\mathrm{U}$ concentrations above $10^{-5} \mathrm{~mol} \mathrm{dm}^{-3}$. In some cases, however, near neutral media were studied where solubility limits of $\mathrm{UO}_{3} \cdot 2 \mathrm{H}_{2} \mathrm{O}$ have been exceeded. (a) Nakajima et al. (1979); (b) Pilar Pons and Fuste (1993); (c) Mann and Fyfe (1984); (d) Tsezos (1983); (e) Hu et al. (1996); (f) Bender et al. (2000); (g) Franklin et al. (2000); (h) Duff et al. (1999); (i) Zhang et al. (1997); (j) Pribil and Marvan (1976); (k) Yang and Volesky (1999a,b); (l) Galun et al. (1984); (m) Guibal et al. (1992); (n) Nakajima and Sakaguchi (1986); (o) Treen-Sears et al. (1984). Liu and $\mathrm{Wu}(1993)$ reported trace levels of $\mathrm{U}$ below $10^{-10} \mathrm{~mol} \mathrm{dm}^{-3}$.

Noubactep et al., 2003). Schoepite is the most soluble U(VI) solid phase. Other solid phases will form only if they are less soluble than schoepite. It is shown that experimental solutions in most cases are below the saturation limit, while a few conditions are reported where precipitation phenomena may have spoiled the reported results. A comparison between theoretical speciation (Fig. 1) and the experimental conditions, however, indicates strongly varying solution conditions, and, hence, quite limited comparability of the reported studies. Nakajima et al. (1979), for example, added sodium carbonate to shift values between $\mathrm{pH} 4$ and $\mathrm{pH} 9$, whereby it remains unclear whether solutions could equilibrate with the atmosphere before the experiments or whether an excess in carbonate remained in solution. Tsezos (1983) applied high concentrations of uranyl nitrate $\left(\mathrm{UO}_{2}\left(\mathrm{NO}_{3}\right)_{2} \cdot 2 \mathrm{H}_{2} \mathrm{O}\right)$ even though nitrate is complexing uranyl(VI). Franklin et al. (2000) worked with chloride solutions even though chloride may form radicals in $\mathrm{U}(\mathrm{VI})$ solutions due to electronic excitation of U(VI) by UV light.

\section{Stage 2: sedimentation}

The first stage in the biological removal of $\mathrm{U}$ is sequestration, and the previous section summarized several methods related to algae, fungi, and bacteria. The next 
stage is to remove these 'biological sequestration units' from the water column. The primary means of sedimentation is simply death. As the cells die, they gradually sink to the bottom of the water column. After death, phytoplankton and bacteria can become aggregated into larger particulates, sinking faster. Algae can also be eaten by zooplankton and herbaceous fish. The resulting faecal pellets are quite dense and sink rapidly to the bottom, carrying the U with them (Fisher et al., 1987).

Sigg (1985) describes the dominant role of biogenic organic particles in binding heavy metals and transferring them into the sediments and shows these processes for fresh water lakes in Switzerland, as they are described in the ocean. This is attributed to the higher primary productivity in these lakes and the generation of more organic particulate matter which adsorbs the metals and carries them out of the water column.

Several researchers have studied $U$ removal in nature at locations such as the Black Sea (Anderson et al., 1989b), the Pacific Ocean near Vancouver/Canada (Anderson et al., 1989a), and in a fjord off the coast of Norway (Swarzenski et al., 1999). All researchers suggest that natural U carbonates become associated with certain natural organic matter such as diatoms and that these diatoms, when dead, sink to the ocean floor, carrying $U$ with them. All of the $U$ found in ocean sediments appears to be bound to organic particulates in exactly the same ratios as is found in sedimenting phytoplankton. However, Sackett et al. (1973) indicate that known sinks account only for about $10 \%$ of the present-day river input of dissolved $\mathrm{U}$.

Bow Lake, northwestern Ontario, contains $20 \mu \mathrm{g} \mathrm{U} \mathrm{kg} \mathrm{g}^{-1}$ of water which represents a tenfold enrichment relative to other lakes from the Canadian Shield (Degens et al., 1979). Land-derived humic compounds and the plankton population (principally diatoms) jointly extracted the $\mathrm{U}$ from the water column; organic material collected by plankton had a $U$ content of $200 \mathrm{mg} \mathrm{kg}^{-1}$. The $U$ was then transferred to the sediments where the concentration in the upper sediments was closer to $300 \mathrm{mg} \mathrm{kg}^{-1}$ sediment.

The role of phytoplankton in the accumulation and transfer of natural radionuclides ( $\mathrm{U}, \mathrm{Th}$, and $\mathrm{Ra}$ ) from the ocean surface to deep waters was assessed by Fisher et al. (1987) from analysis of a number of phytoplankton, zooplankton, sediment trap contents and deep water particles. They concluded that $\mathrm{U}$ and $\mathrm{Ra}$ concentration ratios were similar for phytoplankton, sediment trap material and deep water organic particles.

Koval'skiy and Vorotnitskaya (1965) investigated U concentrations in Chara (Chlorophyta) and in the mud beneath the Chara beds in a shallow Lake Issyk-Kul'. The $U$ accumulated in the organic sediments via adsorption by Chara, then by other filamentous algae. The content of $U$ in the lake sediments depended on the content of organic matter, as $U$ was found mainly associated with algal debris. In the sediments of a stagnant, meromictic lake, Alberic et al. (2000) found U mostly associated with colloidal material (78\%). About 40\% was associated with fulvic and hydrophilic acids. Hence, as particulates break down under anoxic, anaerobic conditions, $\mathrm{U}$ is found to be still associated with the resultant colloidal materials and organic acids.

To study U removal from a seasonally dry lake, sediment and water samples were analyzed for total organic carbon (TOC), U, and other soil parameters (Duff et al., 
1997b). Elevated levels of U enter the lake from irrigation drainage. Sediment and waters were sampled to determine which factors control U solubility and sediment $U$ concentrations. Sediment TOC was correlated with sediment U concentrations, suggesting that $U$ is bound to organic matter. The source of TOC was most likely from algae deposition.

In a follow-up paper, Duff et al. (1999) noted that although the U had been deposited in the sediments via dead algae, the oxidation state of the $U$ was still mostly hexavalent. Comparing the X-ray near-edge absorption data of the pond sediments with the laboratory-produced solids, they concluded that biosorption by algae and bacteria was the dominant mechanism depositing $U$ in the sediments. Mixed oxidation state $U$ solids were preferentially formed in the pond sediments and in the lab except under intense $\mathrm{SO}_{4}$-reducing conditions.

\section{Stage 3: reduction/transformation/biomineralization}

Once the U-algal biomass reaches the sediment interface, it continues to decompose, releasing nutrients and colloidal-bound $U$. If the sediments are undisturbed, the material falls into the benthic boundary layer and remains in the sediments. As the redox conditions decrease with sediment depth, the U(VI) may be reduced to $\mathrm{U}(\mathrm{IV})$. The nutrients that sustain microbial populations in the anaerobic sediments come from natural organic matter (NOM) or algal particles. Algal biomass comes in contact with sediment primarily as decomposing material. Studies on the decomposition of algae suggest that about $60 \%$ of cellular material is mineralized, with the remaining $40 \%$ persisting as particulate material (Foree and McCarty, 1970; Ulen, 1978; Fallon and Brock, 1979; Duff et al., 1999).

The decomposition of algae in the sediments provides nutrients to sustain heterotrophic microbial communities which further degrade organic matter and provide dissolved organic material for anaerobic metal-reducing microbial consortia (Fyson et al., 1998). Algal mats decomposed more slowly in the presence of heavy metals, although $U$ was a metal that least delayed decomposition (Disnar and Trichet, 1984).

The reduction of $\mathrm{U}(\mathrm{VI})$ to $\mathrm{U}(\mathrm{IV})$, as well as the subsequent chemical reactions and transformation to $\mathrm{U}$ sulphide, carbonate, or other biogenic ore requires strongly reducing conditions in the sediment. $\mathrm{U}(\mathrm{VI})$ reduces to $\mathrm{U}(\mathrm{IV})$ at low $\mathrm{E}_{\mathrm{H}}(<200 \mathrm{mV})$ (Fig. 2). This usually requires an anaerobic organic sediment and an active consortium of bacteria, such as sulphate-reducing bacteria (SRB), as well as other microbes to support the consortium. Redox conditions change with proximity to organic sediments. Dissolved oxygen is reduced first, followed by denitrification, followed by $\mathrm{UO}_{2} \mathrm{CO}_{3}$ reduction to uraninite and sulphate reduction to sulphide. At each step in the redox ladder, reactions may be catalyzed by different microbial enzymes. There is a succession of microbial activity from denitrifiers, to metal reducers, to sulphate reducers. Denitrification must be complete before sulphate reducers are activated. It should be noted that the formation of $U(I V)$ requires a considerable over-potential. The often-stated claim that reducing conditions 
automatically involve the formation of poorly soluble U(IV) species has never been proven experimentally. In fact, the claim that U(IV) forms in the presence of zerovalent $\mathrm{Fe}$ has been questioned (Noubactep et al., 2003). Freshly formed U(IV) precipitates are quite soluble. The formation of an amorphous U(IV) oxide on bacteria surfaces has been reported (Abdelouas et al., 1998) with a solubility $\geq 6 \times 10^{-9} \mathrm{~mol} \mathrm{dm}^{-3}$.

In the absence of organic reducing sediments, $U$ bearing particles are released back into the water column when the algae decompose. Brierley and Brierley (1981) grew algae (Chara and Spirogyra; Chlorophyta) in laboratory tanks with and without an organic sediment. The $U$ added to the water was adsorbed by the algae and sank to the bottom of the tank when they died. The $\mathrm{U}$ did not reappear in the water column (e.g. it was reduced and sequestered in the sediments), but was resuspended without sediments. Algal material contributed to some extent to the retention of $U$ in sediment. While Chara alone was unable to significantly affect U levels in the water, the presence of decaying algae resulted in the retention of $U$ in the sediment.

In the oceans, U(VI) carbonate and associated organic matter are sedimented in both organic, anoxic sediments and more oxic sediments (Bloch, 1980). Klinkhammer and Palmer (1991) studied the pore water of various sediment cores and determined that $\mathrm{U}$ diffusing into anoxic sediments remained in the sediments and underwent diagenesis. The $\mathrm{U}$ in more oxic sediments was released back into the water column when the organic matter was degraded. Of the $U$ reaching the sediments, an estimated $75 \%$ remained in the sediments while $20 \%$ was redissolved. Laboratory experiments with ocean sediments carried out by Cochran et al. (1986) also support this view. Anoxic sediments tend to retain U(IV), while more oxic sediments release $U$ after the decomposition of associated organic matter. Kalin et al. (2002) observed that when flow conditions were altered in a drainage basin receiving effluents from a waste rock pile, the shallow portion of one of the lakes in the drainage basin became oxic. The $U$ load did not decrease as was the case in the previous 8 years of the study. This decrease in removal capacity was attributed to $U$ release from the uppermost portion of the sediment.

Barnes and Cochran (1993) have studied U reduction in situ in coastal sediments. The $U$ reduction and subsequent precipitation (removal from pore water) was directly related to bacterially mediated sulphide reduction. The $\mathrm{U}$ was released back into the pore water when the sediments were bioturbed or the sulphate reduction was halted. Uranium release also occurred as $\mathrm{Fe}$ and $\mathrm{Mn}$ were reduced. The authors attribute this to the association of $\mathrm{U}$ with (hydr)oxides of $\mathrm{Fe}$ and possibly $\mathrm{Mn}$ in agreement with laboratory experiments using Fe corrosion products (Noubactep et al., 2003).

The reduction/transformation process has been studied in the laboratory using microbial mats (containing algae, fungi and bacteria) (Bender et al., 2000). The mats were immobilized in silica gel and put in a column. Groundwater containing U was added and passed through the column. Over $80 \%$ of the dissolved U(VI) was removed within $15 \mathrm{~min}$ of treatment. X-Ray near-edge structure spectroscopy showed that the sequestered $U$ was reduced to $U(I V)$ within $24 \mathrm{~h}$. Low redox conditions were maintained by adding nutrients to the columns. 
Francis et al. (1991) studied the reduction of $U$ in sediment samples containing $U$ processing waste. The sediments were amended with glucose and ammonium chloride. Sediments and water were put into serum bottles and left for 50 days. Microbial activity was demonstrated by gas production and by the reduction of $U$ in the water/sediments. They concluded that the reduction of U(VI) was due to the activity of indigenous microbes under anaerobic conditions. While U(VI) was reduced and precipitated, $\mathrm{Fe}(\mathrm{III})$ and $\mathrm{Mn}(\mathrm{IV})$ were reduced and dissolved.

Microorganisms can reduce $\mathrm{U}$ directly by producing $\mathrm{H}_{2} \mathrm{~S}$ or $\mathrm{H}_{2}$ in the course of other processes (abiotic reduction) or directly with enzymes (biotic reduction, such as Geobacter (Delta Proteobacteria) and these bacteria used U as an electron acceptor and $\mathrm{H}_{2}$ or acetate as an electron donor to support growth, and tolerated U(VI) concentrations as high as $8 \mathrm{mM}$.

Lovley and Phillips (1992) used SRB to reduce U(VI). They also tested the effect of toxic metals on the growth of the SRB using Desulfovibrio desulfuricans (Delta Proteobacteria). A pure culture was added to a closed system with lactate and U(VI). Among the anions tested, sulphate, molybdate, and nitrate, and toxic metals, $\mathrm{Cu}$, $\mathrm{Zn}, \mathrm{Co}$, and $\mathrm{Mn}$, only $\mathrm{Cu}$ in high concentrations $(>100 \mathrm{mM})$ inhibited the reactions. Different bacteria require or work better with different organic substrates. Thus, Ganesh et al. (1997) found that reduction of U(VI) required different substrates by Desulfovibrio desulfuricans and Shewanella alga (Delta and Gamma Proteobacteria, respectively). The authors suggested that the best bacterium for the job depended on the organic ligands available in the waste stream.

Lovley (1995) reviewed studies concerning microbial reduction of U(VI) and concluded that the process offered several advantages over currently applied technologies such as ion exchange and biosorption. The advantages included: (i) high removal rate of $U$ per unit of biomass; (ii) reduction and removal of highly soluble U(VI) carbonate complexes; (iii) precipitation of a highly concentrated waste form (amorphous $\mathrm{UO}_{2}$ ) that requires little storage space or that, alternatively, may have commercial value; (iv) the potential of treating mixed waste with organic contaminants as electron donors for the reduction of $\mathrm{U}(\mathrm{VI})$; and (v) the potential for in situ bioremediation of groundwater.

The precipitation of $U$ requires suitable $E_{H} / p H$ conditions in the sediments. It also requires a nucleus, usually one of the consortia bacteria (Beveridge et al., 1983). The precipitate formed can be uraninite $\left(\mathrm{UO}_{2}\right)$, identified by X-ray diffraction and transmission electron microscopy (Gorby and Lovley, 1992). Groudev et al. (2000) studied the transformation of $U$ as it passed through a wetland. They identified and enumerated a number of both aerobic and anaerobic microbial consortia in the low redox sediments, and documented the presence of uraninite. They concluded that the microbial consortia and some biosorption was a viable means of $U$ removal. The process of precipitation can be influenced by other metals such as $\mathrm{Cu}, \mathrm{Zn}, \mathrm{Co}$, and Mn (Lovley and Phillips, 1992).

The geological record attests to the stability of $U$ in deep anaerobic sediments. In Lake Baikal, $\mathrm{U}$ distribution in the sediments has been studied by Edgington et al. (1996). Based on ${ }^{238} \mathrm{U}$ and delta ${ }^{18} \mathrm{O}$ data, $\mathrm{U}$ has not been significantly redistributed within the Baikal sediments over at least the past 250,000 years. 
Spirakis (1996) notes that $U$ ore is often found in association with organic matter and that reduction of $\mathrm{U}$ from (VI) to $\mathrm{U}(\mathrm{IV})$ has long been considered the precipitation mechanism for many types of $U$ deposits. Black shale deposits (Ranstad Shale of Sweden and Chatanooga and New Albany Shales of the USA) contain $U$ associated with organic material and pyrite. He notes that pyrite is formed through the reduction of sulphate by organic matter and that both the adsorption and reduction of $U$ by organic matter may have been involved in the enrichment of $\mathrm{U}$ in black shales.

Spirakis (1996) states that the development of roll-front $U$ deposits is also linked to organic matter. The ore lies at the boundary between altered and unaltered rock; minerals and elements associated with uraninite in the ore include pyrite, $\mathrm{Se}, \mathrm{V}$, organic carbon, $\mathrm{Be}, \mathrm{Cu}, \mathrm{As}$ and Mo. With the exception of Be, the concentration of other elements is consistent with direct reduction or precipitation with sulphide mineral via sulphate reduction. The organic matter in association with the elements initially reduces the sulphate to sulphide and causes pyrite to form. Other U deposits could also be explained by an initial association of $U$ with organic matter in sediments.

Landais (1996) also states that many sedimentary $U$ deposits show close relationships between organic matter and U. According to Landais these relationships may be statistical, spatial or chemical. The chemical relationship is the result of two processes, complexation and reduction. Complexation is understood as the ionic exchange of $U$ with carboxyl groups on humic acids, coals, and kerogens. The other process, reduction, occurs directly or indirectly under low redox conditions. Landais further states that the chemistry of the organic matter is very sensitive to the conditions of deposition and early diagenesis. Organic matter displays different characteristics depending on its origin, e.g. algal, planktonic, or geogenic.

The important final step in the described processes is the long-term immobilization of biologically reduced $U$. If the long-term development of a site would be considered merely from a view point of inorganic processes, the $U$, which is immobilized by reduction and/or mineralization, would easily become remobilized as soon as conditions change. The dashed line denoted ' $\mathrm{Fe}(\mathrm{III}) / \mathrm{Fe}(\mathrm{II})$ ' in Fig. 2 gives the redox boundary of the $\mathrm{Fe}(\mathrm{III}) / \mathrm{Fe}$ (II) redox couple. $\mathrm{Fe}(\mathrm{III})$ can reoxidize U(IV). Several authors have outlined the relevance of biological processes for the development of stable biogenic ore deposits. In a study of 145 minerotrophic wetlands in the mountainous sub-alpine zone of the Rockies, Owen and Otton (1995) documented the vegetation type, and hydrological and topographical conditions of bogs and fens which accumulate $U$ in sediments. Of the 145 bogs investigated, 67 showed U enrichment. In describing surficial U deposits in Canada, Culbert (1984) noted topographic similarities in Manitoba, British Columbia, the Yukon and Nova Scotia. They describe surficial 'young' deposits in semi-arid, alpine and permafrost terrain. Many more examples could be given. However, the deposit formation depends largely on site-specific conditions. The long-term treatment approach would require the creation of shallow basins where phytoplankton and periphytic algae would flourish, to create the pathway from the water to the sediment and fuel the biomineralization. A detailed discussion on the biomineralization of $\mathrm{U}$ is outside the 
scope of this manuscript; the geological literature underscores the importance of detailed investigations of natural analogue sites.

\section{Conclusions}

Uranium (VI) appears in most natural waters as either a cation or complexed with carbonate (uranyl carbonate). As uranyl hydroxide, the molecule is a cation, and as uranyl carbonate, it is an anion. In cationic form, uranyl hydroxide is complexed to living plant, algal, fungal, and bacterial cell walls. It is actively taken up by some taxa but not metabolized by others. In some cells, it is precipitated on cell surfaces and in others internally. Some cells do not interact with the hydroxide at all.

The amount of uranyl ions complexed to cell walls depends on the number and density of the proper ligands in the cell walls. For uranyl, these ligands contain carboxyl groups, which have $\mathrm{p} K$ values between 2.6 and 5 . This means that the optimum $\mathrm{pH}$ for uranyl complexation is between 2.6 and 5 . This is borne out by numerous lab studies.

In the anionic form (as found mostly in high carbonate freshwaters and the ocean), uranyl ions are only partially complexed to plant, bacterial, algal, and fungal cell walls. The ligands present must have a positive charge. Although the ligands present usually must have a positive charge, in alkaline waters some uranyl ions are sequestered in calcium carbonate and calcium phosphate crystals common to the cell walls of some algae.

Algae do not more effectively sequester uranyl ions in their cell walls than other taxa. However, they are a diverse group of plants that can live, grow and reproduce in mining waste water and they are the most abundant and prolific taxa. Thus, understanding and control of the ecological requirements to promote and sustain growth are the underpinning of the treatment approach proposed for decommissioning U waste management areas. Algal cell walls can sequester uranyl ions whether the algae are living or dead because the cell wall structures remain relatively intact upon death. The uranyl ion can be released from these biomaterials by $\mathrm{H}^{+}$ (e.g. high concentrations of acid ( $\mathrm{pH} 2$ or less)). There is, then, a potential for using algal biomass in industrial processes to remove uranyl from waste streams.

For the most part, the sequestration process can be modelled either by Freundlich or Langmuir isotherms, giving us some idea of the mechanisms involved in the complexation of uranyl ions, and in some cases, the maximum sorption capacity.

Once $\mathrm{UO}_{2}^{2+}$ ions become complexed to algal cell wall material, either whole cells, or detritus, the cells will sink to the sediments upon death. Uranyl ion can coordinate with almost any biological material, living or dead, and is transported through the water column to the sediments. This will occur more slowly in well oxygenated, turbulent waters, or faster in anoxic, still waters.

The carbon, nitrogen and phosphorus in the algal detritus are used as nutritional supplements for microbial consortia present on and in the sediments where uranyl reduction and transformation take place. 
Upon reaching the sediments, particulates and bound $U$ can either be buried into the sediments in anoxic areas, or be released and resuspended in more turbulent areas. In combination with a low $\mathrm{E}_{\mathrm{H}}$ environment, sulphates, and minerotrophic microbial systems, the uranyl (VI) can be reduced to tetravalent $\mathrm{U}$ and immobilized as solid phases formed by chemical reactions with sulphates or other anions present in the sediments.

Many of the $U$ ore bodies on the planet are associated with organic matter. Uranium ore diagenesis studied in many locations has been found to have begun with organic matter complexation, microbial reduction, and finally transformation to $U$ and metal sulphides. The ecological approach proposed for the removal of $U$ from waste water follows these natural steps.

\section{Acknowledgements}

CAMECO has supported explorations into the possibilities of Ecological Engineering as a component of the decommissioning for uranium waste management areas. Mark Whittrop and John Jarrel are acknowledged for substantial encouragement and positive criticism.

\section{References}

Abdelouas, A., Nuttall, H.E., Lutze, W., Lu, Y., 1998. In situ removal of uranium from ground water. Proceedings of the International Conference on Tailings and Mine Waste '98, Fort Collins, USA. Balkema, Rotterdam, pp. 669-677.

Abu-Hilal, A.H., 1994. Effect of depositional environment and sources of pollution on uranium concentration in sediment, coral, algae and seagrass species from the Gulf of Aqaba (Red Sea). Marine Pollution Bulletin 28, 81-88.

Alberic, P., Viollier, E.P., Jezequel, D., Grosbois, C., Michard, G., 2000. Interactions between trace elements and dissolved organic matter in the stagnant anoxic deep layer of a meromictic lake. Limnology and Oceanography 45, 1088-1096.

Anderson, R.F., LeHuray, A.P., Fleisher, M.Q., Murray, J.W., 1989a. Uranium deposition in Saanich Inlet sediments, Vancouver Island. Geochimica et Cosmochimica Acta 53, 2205-2213.

Anderson, R.F., Fleisher, M.Q., LeHuray, M.Q., 1989b. Concentration, oxidation state, and particulate flux of uranium in the Black Sea. Geochimica et Cosmochimica Acta 53, 2215-2224.

Andres, Y., MacCordick, H.J., Hubert, J.C., 1994. Binding sites of sorbed uranyl ion in the cell wall of mycobacterial biomass. FEMS Microbiology Letters 115, 27-32.

Barker, W.W., Haas, J.R., Suzuki, Y., Banfield, J.F., 1998. U-Phosphate biomineralization as a mechanism of U fixation by lichen, Geological Society of America, 1998 Annual Meeting, Abstract \#205.

Barnes, C.E., Cochran, J.K., 1993. Uranium geochemistry in estuarine sediments: controls on removal and release processes. Geochimica et Cosmochimica Acta 57, 555-567.

Barton, L.L., Choudhury, K., Thomson, B.M., Steenhoudt, K., Groffman, J.R., 1996. Bacterial reduction of soluble uranium: the first step of in situ immobilization of uranium. Radioactive Waste Management and Environmental Restoration 20, 141-151.

Basnakova, G., Spencer, A.J., Palsgard, E., Grime, G.W., Macaskie, L.E., 1998. Identification of the nickel uranyl phosphate deposits on Citrobacter sp. Environmental Science and Technology 32, 760-765.

Bender, J., Duff, M.C., Phillips, P., Hill, M., 2000. Bioremediation and bioreduction of dissolved U(VI) by microbial mat. Environmental Science and Technology 34, 3235-3241. 
Bengtsson, L., Johansson, B., Hackett, T.J., McHale, L., McHale, A.P., 1995. Studies on the biosorption of uranium by Talaromyces emersonii CBS 814.70 biomass. Applied Microbiology and Biotechnology $42,807-811$.

Beveridge, T.J., Murray, R.G.E., 1980. Sites of metals deposition in the cell wall of Bacillus subtilis. Journal of Bacteriology 141, 876-887.

Beveridge, T.J., Meloche, J.D., Fyfe, W.S., Murray, R.G.E., 1983. Diagenesis of metals chemically complexed to bacteria: laboratory formation of metal phosphates, sulfides, and organic condensates in artificial sediments. Applied Environmental Microbiology 45, 1094-1108.

Bhainsa, K.C., D'Souza, F.S., 1999. Biosorption of uranium(VI) by Aspergillus fumigatus. Biotechnology Techniques 13, 695-699.

Bloch, S., 1980. Some factors controlling the concentration of uranium in the world sea ocean. Geochimica et Cosmochimica Acta 44, 373-377.

Boileau, L., Nieboer, J.R.E., Richardson, D.H.S., 1985. Uranium accumulation in the lichen Cladonia rangiferina. Part I. Uptake of cationic, neutral, and anionic forms of the uranyl ion. Canadian Journal of Botany 63, 384-389.

Brierley, C.L., Brierley, J.A., 1981. Biological Processes for Concentrating Trace Elements from Uranium Mine Waters, WRRI Report No. 140, New Mexico Water Resources Research Institute, Socorro, NM.

Brock, T.D., Smith, D.W., Madigan, M.T., 1984. Biology of Microorganisms, fourth ed. Prentice-Hall, Englewood Cliffs, NJ.

Bustard, M., Donnellan, N., Rollan, A., McHale, L., McHale, A.P., 1996. The effect of pulse field strength on electric field stimulated biosorption of uranium by Kluyveromyces marxianus IMB3. Biotechnology Letters 18, 479-482.

Chang, H.T., Furuya, E.G., Miura, Y., Noll, K.E., 2000. Effect of surface functional groups on Freundlich adsorption isotherm. Water Science and Technology 42, 161-166.

Cochran, J.K., Carey, A.E., Sholkovitz, E.R., Surprenant, L.D., 1986. The geochemistry of uranium and thorium in coastal marine sediments and sediment pore waters. Geochimica et Cosmochimica Acta 50, 663-680.

Culbert, J., 1984. Surficial Uranium Deposits in Canada. IAEA-TecDoc - 332: Surficial Uranium Deposits, Report of the Working Group on Uranium Geology Organized by the International Atomic Energy Agency, pp. 179-192.

Degens, E.T., von Bronsart, G., How Kin, W., Khoo, F., Dickmann, M.D., 1979. Environmental parameters responsible for the fixation of uranium in recent sediments; test area Bow Lake, Ontario, Canada, Part I. Mitteilungen aus dem Geologisch-Palaeontologischen Institut der Universitaet Hamburg, no. 49, pp. 27-60.

Dienemann, C., Dudel, G.E., Dienemann, H., Stolz, L., 2002. Retention of radionuclides and arsenic by algae downstream of U mining tailings. In: Merkel, B.J., Planer-Friedrich, B., Wolkersdorfer, C. (Eds.), Uranium in the Aquatic Environment. Springer Verlag, Berlin/D, pp. 605-613.

Disnar, J.R., Trichet, J., 1984. The influence of various divalent cations $\left(\mathrm{UO}_{2}^{2+}, \mathrm{Cu}^{2+}, \mathrm{Pb}^{2+}, \mathrm{Co}^{2+}, \mathrm{Ni}^{2+}\right.$, $\mathrm{Zn}^{2+}, \mathrm{Mn}^{2+}$ ) on the thermally induced evolution of organic matter isolated from an algal mat. Organic Chemistry 6, 865-874.

Duff, M.C., Amrhein, C., 1996. Uranium (VI) adsorption on goethite and soil in carbonate solutions. Soil Science Society of America Journal 60, 1393-1400.

Duff, M.C., Amrhein, C., Bradford, G., 1997a. Nature of uranium contamination in the agricultural drainage water evaporation ponds of the San Joaquin Valley, California, USA. Canadian Journal of Soil Science 77, 459-467.

Duff, M.C., Amrhein, C., Bertsch, P.H., Hunter, D.B., 1997b. The chemistry of uranium in evaporation pond sediment in the San Joaquin Valley, California, USA, using X-ray fluorescence and XANES techniques. Geochimica et Cosmochimica Acta 61, 73-81.

Duff, M.C., Hunter, D.B., Bertsch, P.M., Amrhein, C., 1999. Factors influencing uranium reduction and solubility in evaporation pond sediments. Biogeochemistry 45, 95-114.

Edington, D.N., Gordon, S.A., Thommes, D.M.U., Almodovar, L.R., 1970. The concentration of radium, thorium, and uranium by tropical marine algae. Limnology and Oceanography 15, 945-955. 
Edgington, D.N., Robbins, J.A., Colman, S.M., Orlandini, K.A., Gustin, M.P., 1996. Uranium-series disequilibrium, sedimentation, diatom frustules, and paleoclimate change in Lake Baikal. Earth and Planetary Science Letters 142, 29-42.

Ekberg, C., Ödegaard-Jensen, A., Meinrath, G., 2003. Ljungskile 1.0 - A computer program for investigation of uncertainties in chemical speciation. REPORT SKI 2003:03, Swedish Nuclear Power Inspectorate, Stockholm, Sweden.

Fallon, R.D., Brock, T.G., 1979. Decomposition of the blue-green algal (cyanobacterial) blooms in Lake Mendota, Wisconsin. Applied and Environmental Microbiology 37, 820-830.

Farrell, J., Bostick, W.D., Jarabek, R.J., Fiedor, J.N., 1999. Uranium removal from ground water using zero valent iron media. Ground Water 37, 618-624.

Fisher, N.S., Teyssie, J.L., Krishnaswami, S., Baskaran, M., 1987. Accumulation of Th, Pb, U, and Ra in marine phytoplankton and its geochemical significance. Limnology and Oceanography 32, $131-142$.

Foree, E.G., McCarty, P.L., 1970. Anaerobic decomposition of algae. Environmental Science and Technology 4, 842-849.

Fourest, E., Volesky, B., 1997. Alginate properties and heavy metal biosorption by marine algae. Applied Biochemistry and Biotechnology 67, 215-226.

Francis, A.J., Dodge, C.J., Gillow, J.B., Cline, J.E., 1991. Microbial transformation of uranium in wastes. Radiochimica Acta 52/53, 311-316.

Franklin, N.M., Stauber, J.L., Markich, S.J., Lim, R.P., 2000. pH-dependent toxicity of copper and uranium to a tropical freshwater alga (Chlorella sp.). Aquatic Toxicology 48, 275-289.

Freundlich, H., 1926. Colloid and Capillary Chemistry. Mathuen, London.

Fyson, A., Nixdorf, B., Kalin, M., Steinberg, C.E.W., 1998. Mesocosm studies to assess acidity removal from acidic mine lakes through controlled eutrophication. Ecological Engineering 10, 229-245.

Galun, M., Keller, P., Malki, D., Feldstein, H., Galun, S., Siegel, S., Siegel, B., 1984. Removal of uranium(VI) from solution by fungal biomass: inhibition by iron. Water, Air, and Soil Pollution 21, 411-414.

Ganesh, R., Robinson, K.G., Reed, G.D., Sayler, G.S., 1997. Reduction of hexavalent uranium from organic complexes by sulfate- and iron-reducing bacteria. Applied and Environmental Microbiology $63,4385-4391$.

Golab, Z., Orlowska, B., Smith, R.W., 1991. Biosorption of lead and uranium by Streptomyces sp. Water, Air, and Soil Pollution 60, 99-106.

Goldberg, E.L., Gracher, M.A., Bobrov, U.A., 1998. Do diatom algae structures accumulate uranium? Nuclear Instrumentation and Methods A 405, 584-589.

Gorby, Y.A., Lovley, D.R., 1992. Enzymatic uranium precipitation. Environmental Science and Technology 26, 205-207.

Greene, B., Henzl, M., Hosea, J.M., Darnall, D.W., 1986. Elimination of bicarbonate interference in the binding of U(VI) in mill-waters to freeze-dried Chlorella vulgaris. Biotechnology and Bioengineering 28, 764-767.

Groudev, S.N., Georgiev, P.S., Komnitsas, K., Spasova, I.I., Angelov, A.T., 2000. Treatment of waters contaminated with radioactive elements and toxic heavy metals by a natural wetland. In: Means, J., Hinchee, R. (Eds.), Wetlands and Remediation: An International Conference. Battelle Press, Salt Lake City, UT, pp. 391-397.

Gu, B., Liang, L.P.A., Dickey, M.J., Yin, X., Dai, S., 1998. Reductive precipitation of uranium(VI) by zero-valent iron. Environmental Science and Technology 32, 3366-3373.

Guibal, E., Roulph, C., Le Cloirec, P., 1992. Uranium biosorption by a filamentous fungus Mucor miehei: pH effect on mechanisms and performances of uptake. Water Research 26, 1139-1145.

Haas, J.R., 1998. A comparison of $U$ and lanthanide bioaccumulation by some common lichens, Geological Society of America, Annual Meeting, Toronto, 30, pp. 204-205.

Haas, J.R., Bailey, E.H., Purvis, O.W., 1997. Bioaccumulation of aqueous uranium by lichens; the influence of surface phosphate groups on short-term uptake and release? Seventh Annual V.M. Goldschmidt Conference, Tuscon, AZ, Vol. 921, pp. 84-85.

Haas, J.R., Bailey, E.H., Purvis, O.W., 1998. Bioaccumulation of metals by lichens; uptake of aqueous uranium by Peltigera membranancea as a function of time and $\mathrm{pH}$. American Mineralogist 83, 1494-1502. 
Haas, J.R., Dichristina, T.J., Wade Jr., R., 2001. Thermodynamics of U(VI) sorption onto Shewanella putrefaciens. Chemical Geology 180, 33-54.

Hafez, N., Abdel-Razek, A.S., Hafez, M.B., 1997. Accumulation of some heavy metals on Aspergillus flavus. Journal of Chemical Technology and Biotechnology 68, 19-22.

Halbach, P., von Borstel, D., Gundermann, K.D., 1980. The uptake of uranium by organic substances in a peat bog environment on a granitic bedrock. Chemical Geology 29, 117-138.

Heide, E.A., Wagener, K., Paschke, M., Wald, M., 1973. Extraction of uranium from sea water by cultured algae. Naturwissenschaften $60,431$.

Horikoshi, T., Nakajima, A., Sakaguchi, T., 1979. Uptake of uranium by Chlorella regularis. Agricultural and Biological Chemistry 43, 617-623.

Horikoshi, T., Nakajima, A., Sakaguchi, T., 1981. Accumulation of uranium by Chlorella cells grown under autotrophic, heterotrophic and mixotrophic culture conditions. Agricultural and Biological Chemistry 45, 781-783.

Hu, Z.C., Norman, J.M., Faison, B.D., Reeves, M.E., 1996. Biosorption of uranium by Pseudomonas aeruginosa strain CSU: characterization and comparison studies. Biotechnology and Bioengineering $51,237-247$.

Hunt, S., 1986. Diversity of biopolymer structure and its potential for ion-binding applications. In: Eccles, H., Hunt, S. (Eds.), Immobilization of Ions by Bio-sorption. Ellis Horwood, Chichester, pp. 15-46.

IAEA, 1992. The Chemical Thermodynamics of Actinide Elements and Compounds. Part XII. The Actinide Aqueous Inorganic Complexes. IAEA, Wien/Austria.

Justyn, J., Stanek, Z., 1974. Accumulation of natural radionuclides in the bottom sediments and by aquatic organisms of streams. International Revue Gesamten Hydrobiologie 59, 593-609.

Kalin, M., Wheeler, W., 1992. Periphyton growth and zinc sequestration, BIOMINET Annual General Meeting, Edmonton, 9, pp. 49-64.

Kalin, M., Smith, M.P., Wittrup, M.B., 2002. Ecosystem restoration incorporating minerotrophic ecology and Stoneworts that accumulate 226 Ra. In: Merkel, B.J., Planer-Friedrich, B., Wolkersdorfer, C. (Eds.), Uranium in the Aquatic Environment. Proceedings of the International Conference Uranium Mining and Hydrogeology III and the International Mine Waster Association Symposium, Freiberg, Germany, 15-21 September 2002. Springer, pp. 495-504.

Klinkhammer, G.P., Palmer, M.R., 1991. Uranium in the oceans: where it goes and why. Geochimica et Cosmochimica Acta 55, 1799-1806.

Koval'skiy, V.V., Vorotnitskaya, I.Y., 1965. Biogenic migration of uranium in Lake Issyk-Kul'. Geokhimiya 6, 724-732.

Krueger, S., Olson, G.J., Johnsonbaugh, D., Beveridge, T.J., 1993. Characterization of binding of gallium, platinum, and uranium to Pseudomonas fluorescences by small-angle x-ray scattering and transmission electron microscopy. Applied and Environmental Microbiology 59, 4056-4064.

Landais, P., 1996. Organic geochemistry of sedimentary uranium ore deposits. Ore Geology Reviews 11, $33-51$.

Langmuir, I., 1918. The adsorption of gases on plane surfaces of glass, mica and platinum. Journal of the American Chemical Society 40, 1361-1403.

Liu, H.-H., Wu, J.T., 1993. Uptake and recovery of americium and uranium by Anacystis biomass. Journal of Environmental Science and Health Part A: Environmental Science and Engineering 28, 491-504.

Lobban, C.S., Wynne, M.J., 1981. The Biology of Seaweeds. Blackwell Scientific Publications, Oxford.

Lovley, D.R., 1995. Bioremediation of organic and metal contaminants with dissimilatory metal reduction. Journal of Industrial Microbiology 14, 85-93.

Lovley, D.R., Phillips, E.J.P., 1992. Bioremediation of uranium contamination with enzymatic uranium reduction. Environmental Science and Technology 26, 2228-2234.

Macaskie, L.E., Bonthrone, K.M., Yong, P., Goddard, D.T., 2000. Enzymically mediated bioprecipitation of uranium by Citrobacter sp.: a concerted role for exocellular lipopolysaccharide and associated phosphatase in biomineral formation. Microbiology 146, 1855-1867.

Mann, H., Fyfe, W.S., 1984. An experimental study of algal uptake of U, Ba, V, Co and Ni from dilute solutions. Chemical Geology 44, 385-398. 
Mann, H., Fyfe, W.S., 1985. Uranium uptake by algae; experimental and natural environments. Canadian Journal of Earth Sciences 22, 1899-1903.

Marques, A.M., Bonet, R., Simon-Pujol, M.D., Fuste, M.C., Congregado, F., 1990. Removal of uranium by an exopolysaccharide from Pseudomonas sp. Applied Microbiology and Biotechnology $34,429-431$.

McCready, R.G.L., Lakshmanan, V.I., 1986. Review of bioabsorption research to recover uranium from leach solutions in Canada. In: Eclles, S. (Ed.), Immobilisation of Ions by Bio-sorption. Canada Centre for Mineral and Energy Technology, Energy Mines and Resources Canada, Ottawa, pp. 219-225.

McLean, R.J.C., Beveridge, J.J., 1990. Metal-binding capacity of bacterial surfaces and their ability to form mineralized aggregates. In: Ehrlich, H.L., Brierley, C.L. (Eds.), Microbial Mineral Recovery. McGraw-Hill Publishing Co., New York, pp. 185-222.

Meinrath, A., Schneider, P., Meinrath, G., 2003. Uranium ore and depleted uranium in the environment, with a reference to uranium in the biosphere from the Erzgebirge/Sachsen, Germany. Journal of Environmental Radioactivity 64, 175-193.

Meinrath, G., 1996. Coordination of uranyl(VI) carbonate species in aqueous solutions. Journal of Radioanalytical and Nuclear Chemistry 211, 349-362.

Meinrath, G., 1997. Uranium(VI) speciation by spectroscopy. Journal of Radioanalytical and Nuclear Chemistry 224, 119-126.

Meinrath, G., 1998a. Aquatic chemistry of uranium - a review focusing on aspects of environmental chemistry. Freiberg Online Geoscience, vol. 1, 99. S. Available from: http://www.geo.tu-freiberg. de/fog.

Meinrath, G., 1998b. Direct spectroscopic speciation of schoepite-aqueous phase equilibria. Journal of Radioanalytical and Nuclear Chemistry 232, 179-188.

Meinrath, G., Kato, Y., Kimura, T., Yoshida, Z., 1996. Solid-aqueous phase equilibria of uranium(VI) under ambient conditions. Radiochimica Acta 75, 159-167.

Morel, F.M.M., Hudson, R.J.M., 1985. The geobiological cycle of trace elements in aquatic systems: Redfield revisited. In: Stumm, E. (Ed.), Chemical Process in Lakes. Wiley, New York, pp. 251-281.

Morrison, S.J., Spangler, R.R., Tripathi, V.S., 1995. Adsorption of uranium (VI) on amorphous ferric oxyhydroxide at high concentrations of carbon (IV) and sulphur (VI). Journal of Contaminant Hydrology 17, 333-346.

Myers, V.B., Iverson, R.L., Harriss, R.C., 1975. The effect of salinity and dissolved organic matter on the surface charge characteristics of some euryhaline phytoplankton. Journal of Experimental Marine Biology and Ecology 17, 59-68.

Nakajima, A., Sakaguchi, T., 1986. Selective accumulation of heavy metals by microorganisms. Applied Microbiology and Biotechnology 24, 39-64.

Nakajima, A., Horikoshi, T., Sakaguchi, T., 1979. Ion effects on the uptake of uranium by Chlorella regularis. Agricultural and Biological Chemistry 43, 625-629.

Nash, K., Fried, S., Friedman, A.M., Sullivan, J.C., 1981. Redox behavior, complexing and adsorption of hexavalent actinides by humic acid and selected clays. Environmental Science and Technology 15, 834-837.

Neihof, R.A., Loeb, G.L., 1972. The surface charge of particulate matter in seawater. Limnology and Oceanography 17, 7-16.

Noubactep, C., Meinrath, G., Dietrich, P., Merkel, B., 2003. Mitigation of uranium in groundwater: prospects and limitations. Environmental Science and Technology 37, 4304-4308.

Ödegaard-Jensen, A., Ekberg, C., Meinrath, G., 2004. LJUNGSKILE, a program for assessing uncertainty in speciation calculations. Talanta, in press.

Omar, N.B., Merroun, M.L., Gonzalez-Munoz, M.T., Arias, J.M., 1996. Brewery yeast as a biosorbent for uranium. Journal of Applied Bacteriology 81, 283-287.

Owen, D.E., Otton, J.K., 1995. Mountain wetlands: efficient uranium filters - potential impacts. Ecological Engineering 5, 77-93.

Ozer, A., Ozer, D., Dursun, G., Bulak, S., 1999. Cadmium(II) adsorption on Cladophora crispata in batch stirred reactors in series. Waste Management 19, 233-240. 
Pearson, R.G., 1963. Hard and soft acids and bases. Journal of the American Chemical Society 84, 3533-3539.

Pilar Pons, M., Fuste, M.C., 1993. Uranium uptake by immobilized cells of Pseudomonas strain EPS 5028. Applied Microbiology and Biotechnology 39, 661-665.

Pribil, S., Marvan, P., 1976. Accumulation of uranium by the chlorococcal alga Scenedesmus quadricauda. Archiv fuer Hydrobiologie, Supplement 49, 214-225.

Rai, L.C., Gaur, J.P., Kumar, H.D., 1981. Phycology and heavy-metal pollution. Biological Reviews of the Cambridge Philosophical Society 56, 99-151.

Riordan, C., Bustard, M., Putt, R., McHale, A.P., 1997. Removal of uranium from solution using residual brewery yeast: combined biosorption and precipitation. Biotechnology Letters 19, 385-387.

Roig, M.G., Manzano, T., Diaz, M., 1997. Biochemical process for the removal of uranium from acid mine drainages. Water Research 31, 2073-2083.

Rojickova-Padrtova, R., Marsalek, B., 1999. Selection and sensitivity comparisons of algal species for toxicity testing. Chemosphere 38, 3329-3338.

Sackett, W.M., Mo, T., Spalding, R.F., Exner, M.E., 1973. A reevaluation of the marine geochemistry of uranium. Symposium on the Interaction of Radioactive Contaminants. IAEA, Vienna/A, pp. 757-769.

Sar, P., D'Souza, S.F., 2001. Biosorptive uranium uptake by a Pseudomonas strain: characterization and equilibrium studies. Journal of Chemical Technology and Biotechnology 76, 1286-1294.

Scheminzky, F., 1959. Ueber Urananreicherung in niederen Pflanzen. Fundamenta Balneo-Bioclimatologica $1,117-132$.

Segel, I.H., 1976. Biochemical Calculations, second ed. John Wiley and Sons, New York.

Sigg, L., 1985. Metal transfer mechanisms in lakes: the role of settling particles. In: Stumm, W. (Ed.), Chemical Processes in Lakes. John Wiley and Sons, New York, pp. 283-310.

Spirakis, C.S., 1996. The roles of organic matter in the formation of uranium deposits in sedimentary rocks. Ore Geology Review 11, 53-69.

Swarzenski, P.W., McKee, B.A., Skei, J.M., Todd, J.F., 1999. Uranium biogeochemistry across the redox transition zone of a permanently stratified fjord; Framvaren, Norway. Marine Chemistry 67, $181-198$.

Szalay, A., 1964. Cation exchange profiles of humic acids and their importance in the geochemical enrichment of $\mathrm{UO}_{2}^{++}$and other cations. Geochimica et Cosmochimica Acta 28, 1605-1614.

Thomas, R.A.P., Macaskie, L.E., 1998. The effect of growth conditions on the biodegradation of tributyl phosphate and potential for the remediation of acid mine drainage waters by a naturally-occurring mixed microbial culture. Applied Microbiology and Biotechnology 49, 202-209.

Tien, C.-J., 2002. Biosorption of metal ions by freshwater algae with different surface characteristics. Process Biochemistry 38, 605-613.

Titayeva, N.A., 1967. Association of radium and uranium with peat. Geokhimiya 12, 1493-1499.

Treen-Sears, M.E., Volesky, B., Neufeld, R.J., 1984. Ion exchange/complexation of the uranyl ion by Rhizopus biosorbent. Biotechnology and Bioengineering 26, 1323-1329.

Tsezos, M., 1983. The role of chitin in uranium adsorption by $R$. arrhizus. Biotechnology and Bioengineering 25, 2025-2040.

Tsezos, M., Volesky, B., 1982. The mechanism of uranium biosorption by Rhizopus arrhizus. Biotechnology and Bioengineering 24, 385-401.

Tsezos, M., Georgousis, Z., Remoudaki, E., 1997. Mechanism of aluminum interference on uranium biosorption by Rhizopus arrhizus. Biotechnology and Bioengineering 55, 16-27.

Ulen, B., 1978. Seston and sediment in lake Norrviken. II. Aerobic decomposition of algae. Schweizerische Zeitschrift für Hydrologie 40, 104-118.

Volesky, B., May-Phillips, H.A., 1995. Biosorption of heavy metals by Saccharomyces cerevisiae. Applied Microbiology and Biotechnology 42, 797-806.

Wetzel, R.G., 1983. Periphyton of Freshwater Ecosystems. Dr. W. Junk Publishers, Den Haag/NL.

Wielinga, B., Bostick, B.C., Rosenzweig, R.F., Fendorf, S.E., 1999. Competitive inhibition of microbial uranium reduction by amorphous ferric hydroxides. Abstracts of the General Meeting of the American Society for Microbiology 99, 535. 
Wielinga, B., Bostick, B.C., Hansel, C.M., Rosenzweig, R.F., Fendorf, S.E., 2000. Inhibition of bacterially promoted uranium reduction: ferric (hydr)oxides as competitive electron acceptors. Environmental Science and Technology 34, 2190-2195.

Williams, R.J.P., 1981. Physico-chemical aspects of inorganic element transport through membranes. Philosophical Transactions of the Royal Society of London B 294, 57-74.

Wright, J.V., Conca, J.L., 2002. Remediation of groundwater and soil contaminated with metals and radionuclides using apatite II, a biogenic apatite mineral, American Chemical Society General Meeting, 224, 124-ENVR, Boston.

Yang, J., Volesky, B., 1999a. Modeling uranium-proton ion exchange in biosorption. Environmental Science and Technology 33, 4079-4085.

Yang, J., Volesky, B., 1999b. Biosorption of uranium on Sargassum biomass. Water Research 33, $3357-3363$.

Zhang, X., Luo, S., Yang, Q., Zhang, H., Li, J., 1997. Accumulation of uranium at low concentration by the green alga Scenedesmus obliquus 34. Journal of Applied Phycology 9, 65-71. 